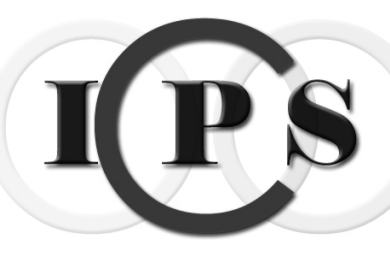

\title{
Sex talk: mutuality and power in the shadow of HIVIAIDS in Africa
}

\author{
Dr. Janet Bujra
}

ICPS WORKING PAPER 8

University of Bradford 


\section{Previous Titles in this Series}

Working Paper 1 (2005)

Jenny Pearce and Heather Blakey

'Background of Distances' Participation and Community Cohesion in the North:

Making the Connections

Working Paper 2 (2005)

Heather Blakey

Participation... Why Bother? The Views of Black and Minority Ethnic Mental

Health Service Users on Participation in the NHS in Bradford

Working Paper 3 (2007)

Graeme Chesters and lan Welsh

The Death of Collective Identity? Global Movement as a Parallelogram of Forces

Working Paper 4 (2007)

Jelke Boesten

Precarious Future: Community volunteers and HIVIAIDS in a Tanzanian roadside town

Working Paper 5 (2007)

Jelke Boesten

AIDS Activism, Stigma and Violence: A literature review

Working Paper 6 (2007)

Lisa Cumming

Programme for a Peaceful City: Systematising an Experience

2001-2006

Working Paper 7 (2007)

Martin Pearson

Building Community Interaction in Three Post Industrial and Multi-ethnic Northern 'Cities': Perspectives from Bradford, Burnley and Oldham on Five Years of Learning following the 2001 Disturbances.

Series editor:

Maggie Bolton, Department of Peace Studies, University of Bradford 


\title{
Sex talk: mutuality and power in the shadow of HIVIAIDS in Africa
}

\author{
Dr. Janet Bujra
}

ICPS WORKING PAPER 8 


\begin{abstract}
Bids for mutuality in sexual partnerships are key to AIDS campaigning slogans such as 'negotiate', 'know your partner' and 'use condoms'. This paper explores the contradiction between more mutuality in sexual relations and the gender power politics that render such mutuality difficult to achieve in Africa, as well as the caricatures of 'African sexuality' that have pervaded some of the literature. It looks at the new discourses of sexuality delivered via NGOs and the state as well as the ways in which customary silences about sex are being broken by ordinary people. It asks whether, given the threat of HIV infection, people are talking in new ways about sexual relationships, and how this talk is gendered. It also addresses the challenge to African feminism of sexuality discourses and how these need to be rethought in the context of AIDS. It concludes that the prospect of death by sex is transforming discourses, challenging customary sexual practice and putting gendered inequalities in question.
\end{abstract}

\title{
The Author
}

Janet Bujra is an Honorary Research Associate and Reader at the International Centre for Participation Studies. She is a sociologist who has carried out a lifetime of research in Africa and in Britain, particularly around the issues of gendered politics and class relations. 
Sex talk: mutuality and power in the shadow of HIVIAIDS in Africa

\author{
Janet Bujra \\ University of Bradford
}

One of the most revolutionary outcomes of attempts to address AIDS in Africa has been the objectification of sexuality through 'breaking silences' and critically addressing sexual practice - a rethinking in which all have been caught up. The process of confronting AIDS is beset with contradictions which may allow for the realisation of an emancipatory project in terms of safer sex and more equal gendered sexual relations, or it may simply entrench existing inequities. Pleas for more mutuality in sexual relations which are embedded in AIDS campaigns in Africa can be seen as wishful thinking, and some have warned against their apparent naiveté. My argument here will be that if we listen to what ordinary people say, it is evident that in response to the threat of AIDS such messages are being taken up, at least rhetorically, and that the crisis is driving a reconsideration of all aspects of sexuality including the gendered relations between sexual partners and indeed gender itself. Other factors have played a part in such rethinking and reworking, but the threat of the epidemic, with its prospect of death for self and future generations, and its souring of the enjoyment of sex, is one of the most potent.

Acknowledgement of this significant level of novel dialogue has been overshadowed by caricatures of 'African sexuality' - in turns understood as exotic, as highly permissive and promiscuous, as imprisoned in tribal taboo and prohibition, as exclusively focussed on reproduction - and, in some more recent postmodern versions, as 'playful' and self-referential. Given the social diversity of this huge continent, there is no such object as 'African sexuality', and the response to HIV has varied as localised practice or custom in relation to sex inadvertently inhibits or allows its transmission. There are, however, some features of the African AIDS crisis which are more generalised and which distinguish it from the global phenomenon. First is the extent to which HIV had already spread before medical intervention could make any difference (see e.g. Hooper 2000; Iliffe 2006). Second is the level of impoverishment which has accompanied the limited transformation of extractive economies in postcolonial Africa (continuing producer of raw materials, minerals and monocrops for multinationals), and the related movement of populations, going back to colonial times, especially of young males, for migrant wage labour and more recently for operation in armies and militias, as well as the displacement of vast numbers fleeing armed conflict. Transmission, predominantly through heterosexual networking, was entrenched almost before the disease was named, and it 
travelled across the boundaries of ethnicity, class, nation and continent which had already been breached through globalising tendencies.

The globalisation of the epidemic and the localisation of the epidemic are both crucial to addressing what is to be done. One aspect of globalisation is the way that campaigning against AIDS in Africa has been conducted by states weakened in their role as health service providers by the structural adjustment programmes of IFIs and foreign donors, and through NGO-isation, for a time the favoured alternative to state provision. Whilst there is also a groundswell of grassroots organising on the multiple challenges thrown up by AIDS, most of this is dependent on foreign benefactors. The far-reaching implications of this for local power relations will be explored later, but it is worth beginning with the ideological impact.

In a set of workshops with rural women held in Tanzania in 1996 , one of the facilitators, a woman teacher from an urban area, declaimed: "We are women, and we understand the problem of men ruling in the home. They can beat you! But we must tell them - should both of us die? Shall we leave the children without parents? Please, let us use this thing [condom] out of love for each other. Many will agree. Women are afraid of men, but men are also afraid of women of them refusing too, or of getting infected from women".

A direct appeal is made here to common positioning and experience as women, irrespective of contrasting class origins. The message is powerful but also shocking. It demands that if people want to live in this era of AIDS, then they need to completely transform the way they do sex. They need to rethink the very terms of their own sexuality, both within marriage and without. Most significantly it appeals for a high degree of mutuality between sexual partners, and for women in particular to fight for this, on pain of death.

Messages of mutuality in sexual relations are central to AIDS campaigning: 'be faithful', 'know your partner', 'negotiate', 'use condoms' are endlessly reiteratedii. In situations where heterosexual transmission predominates, this demands an equality of the sexes in the settings for sexual encounters where in practice the power of men prevails - marriage, casual relations, commercial sex. Demands for safer sex via greater mutuality thereby put power into question. This is not to deny that these are also sites where women have some degree of agency. However, as locations of micro power politics and struggles, they are not settings generally marked by the respect, openness, equity and honesty which might protect both parties from infection. Mutuality can also be held to mean that both sexes have an equal right to sexual fulfilment. This is a revolutionary claim which threatens male control of sexuality, as women have discovered in many other times and places. For a long time, African feminists evaded the topic of sexuality, seeing it as an obsessive concern of 'Western feminists' (see e.g. Amadiume 1987: 9); now AIDS has forced it onto the agenda. 
A discourse of mutuality in sexual relations derives from a history of intellectual and political struggles in Europe and America, a history in which 'sexuality' was isolated as a separable sphere of discourse and practice particularly through the work of Freud, but also in the context of a birth control movement focussed on the working class and of the rise of middle-class feminism. In the 1930s activists campaigned for women's right to satisfy desire (see Bland 1996) whilst writers such as Marie Stopes and Helena Wright wrote about the possibility of married love. Some have argued that in Africa, messages of mutuality are out of place. Standing and Kisekka, writing in the early period of AIDS organising, argued that "campaigns founded on concepts of consent and mutual satisfaction are likely to be quite inappropriate", even "unrealistic" (1989: vi). More recently, Phillips questions campaigns based on "joint fidelity" as bordering on "criminal naïveté" (2004: 164) and Haram suggests that culturally prescribed secrecy about sexual adventures is a barrier to the honesty and openness needed between partners for safe sex (2005: 14). Here I ask whether, despite the transgressive nature of sex talk, AIDS may have rendered mutuality a subject on which to speak and to act. Drawing on research in Lushoto in Tanzania, I provide evidence of men and women talking about sex in new ways and imagining a wholly different way of conducting sexual relations. Whilst this data illustrates the disturbing impact of the arrival of AIDS in one small area of Tanzania, the point is certainly more general and I therefore draw on a wider literature to engage with the proposition that AIDS has put sex in question all over Africa, and has generated new discourses around sexuality in which all are involved, from farmers to feminists.

AIDS has pathologised not only 'immoral sex', but also 'normal' acceptable sex between married couples because of its characteristic heterosexual transmission. Its far reaching impact is transforming strategic conjunctures of power at all levels, in so far as controlling sexuality has always been at issue for the powerful. I consider here how the directive power of husbands and fathers, men in general, local leaders and the state has been put in question. Conversely, novel prospects of power to transform with others (Rowlands 1997) have been given a spur by the 'new experts' of the NGO/INGO community, but equally by women themselves, daring to talk and to challenge. At issue here then, is the extent to which the promise of mutuality in gendered sexual relations, inscribed in AIDS campaigns, could be delivered in the context of new and old relations of power. This is linked to the way sexuality has been conceptualised in Africa.

\section{‘African sexuality'?}

Although richly diverse accounts of sexual practice in Africa are to be found in the anthropological literature, monocausal arguments about 'African sexuality' were generated by evidence of an incipient AIDS epidemic in the region. For some investigators there was a typical form of sexuality in Africa which had at the very least facilitated the spread of AIDS. The most well-known of such commentators were Caldwell, Caldwell and Quiggin in their article "The social context of AIDS in Sub-Saharan Africa" (1989). Unsurprisingly they present a 
model of Africa as composed of discrete and differentiated ethnic units, with a heavy emphasis on what was customary or 'traditional' rather than what is negotiated or changing. Despite their evidence of considerable diversity in patterns of sexuality, the focus is rather on what is held to be general and problematic about Africa. Most fundamentally this revolves around extensive "sexual networking" and "fairly permissive... sexual attitudes" (222) in relation to premarital chastity and adultery, but also to births out of wedlock, and a claimed lack of guilt about illicit sex. Procreation is said to be regarded as more important than sex, with fertility as the highest value, but since children are attached to a lineage or wider kinship group, conjugal unions are not close and divorce is easy. More surprising is the claim that African "societies are not really patriarchal ... for there is not the same obsession that the term usually implies with controlling the morals and mobility of women. The permissiveness ... [is] an integral part of the whole society that has given women great freedom" (222-3). It is the extent of female 'freedom' that is held up as scene setting for sexual networking and for HIV transmission.

Extensively rejected and criticised in detail, especially by feminists with knowledge of the predominately patrilineal settings in Africa where controlling women's sexuality is central to male power (see e.g. Ahlberg 1994; Heald 1995), this account has also been seen as consonant with bids to blame women for the epidemic. However, whilst questioning the thesis, feminists have also noted that, perversely, it acknowledges women's independent bids for sexual autonomy and satisfaction of desire. It is this ambiguity that leads Arnfred (2004) to allow for a "feminist reading" of Caldwell et al. Later I will suggest that this is also problematic in the context of AIDS.

An alternative text of the same year as Caldwell et. al., that of Standing and Kisekka (1989), presents a far more nuanced picture, despite their material being similarly grounded in anthropological texts rooted in ethnically bounded versions of sexuality. An annotated bibliography of materials collated to assist those who have to address the AIDS crisis, it corrects some of the misrepresentations embedded in the Caldwell et al text. For example, they point out that it is perverse to insist that 'fertility is all' in African sexuality - this may be prioritised in marital sex, but not in non-marital or extra-marital relations (vi). As they note, this situational awareness is vital in promotion of safer sex and condom use campaigns. This leaves open the question of whether a fairly exclusive focus on fertility is predominant even in marital sex, a point to which I return. What is notable about Standing and Kisekka's account of sexuality in Africa is certainly not female sexual freedom or permissiveness in general, but the extent of restriction and regulation of sexual encounters. Rather than promiscuous and hedonistic relations between equals, sex is presented as an encounter between unequals and policed by those who wield power in social life in general.

It is undeniable that there are variations in the extent to which African women were and are able to express their sexual desires openly and freely. Drawing on 
Standing and Kisekka's 1989 survey, I note the extreme contrasts. Writing as a Somali, Riqiya Haji Dualeh describes how women endure early female circumcision (infibulation) which makes pre-marital sex impossible and how "the inevitable painful sexual intercourse that women experience during ...their wedding is often a cause for celebration and boasting by the men as proof of their dominant male image" (1983, Standing and Kisekka's summary: 1989: 112). This produced a "repressed and oppressed sexuality" for women, in which they learned to inhibit their sexual urges. By comparison, in matrilineal Luapula, Zambia, sex is viewed as "healthy pleasure ...Both sexes are expected to be sexually active and for women, monopolisation by one man is considered to be dangerous as it undermines the interests of the matrilineage" (1981, Poewe, Standing and Kisekka's summary: 190). A matrilineal system of kinship does not necessarily mean that women have more sexual 'freedom' or are less subject to male control, but it does mean that fatherhood is not the basis for a child's legitimacy, and although a variety of patterns emerge, the conjugal bond is weak and less exclusive than in patrilineal systems, where rights to a women's reproductive capacities and control over her sexuality pass from her natal lineage to that of her husband (Malinowski noted this difference as early as 1923). Despite the contrasts, sexual expression is rule-governed in either case.

That mutual sexual pleasure is not excluded in regulated sexual relations can also be imputed from this study. Kisekka offers an unusually frank account of the diversity of practices in Uganda in the 1980s, based on first hand interviews with both men and women (1989). To quote a few of the findings: "Ankole people are reputed in Uganda for a sex act called kakapali which involves mutual masturbation with a man's penis stroking the clitoris. This style is believed to produce multiple orgasms - both the man and woman take turns in manipulating the penis over the clitoris. There is expectation of two sexual acts a night [with] penetrative sex" (1989: 211). Baganda informants spoke of the "art of lovemaking. Praises, romantic and flattering phrases, rhythmic movements, ecstatic groans are all part of the sexual act...aggressive sex is despised" (215). Mutuality and the pursuit of sexual pleasure irrespective of reproduction are here in evidence ${ }^{i i i}$. More ambiguously, female resistance to male power is also seen as a sexual stimulant - for the Bakonjo, men "preferred some resistance as a way of creating excitement" (217). Amongst the twelve cases cited by Kisekka, there are only two where women are expected to be totally passive: for the Ateso for example, "the sex act is conducted briskly without foreplay [or] any degree of participating response on the part of a woman" (214).

Whilst the pursuit of sexual pleasure may be highly valued by both sexes, it is never untrammelled. Masturbation, homosexuality, oral sex are often proscribed in these accounts; and periods of abstinence, sexual hygiene and acceptable partners are prescribed. Clearly, with the onset of AIDS, campaigns for protection must attend to the local variations of regulated sexuality in so far as they affect the potential for transmission, noting that some proscribed sexual activities (such as masturbation) may in fact be forms of safer sex. More devastating to local 
understandings is that it is now not just proscribed forms of sexual behaviour which bring the deadly infection - homosexuality, adultery, prostitution - but also what were licit, approved, accepted forms of behaviour, especially heterosexual marriage. Other normative practices such as polygyny, widow inheritance, male and female circumcision, dry sexiv, marriage by capture, all now come to be seen as dangerous and risky. The very diversity of sexual expression in Africa which Standing and Kisekka document here is likely to dissolve under an externally prescribed uniformity of safe sex.

According to Adams and Pigg, "we can read this creation of 'normative' sex as a modern project deeply tied to the fields of colonial and postcolonial health development, and nationalism, in and through [biomedical] science" (2005: 159). There is considerable strength in this argument, though in the context of AIDS it marginalises the impact on 'normativity' of ordinary people practising sex under the shadow of death. More promising is their suggestion that what are produced in the current situation are 'new subjectivities' around sex - perhaps we should say 'critical subjectivities', though with the proviso that more is carried here than individual self-expression and feeling. From this postmodernist perspective there is no question of imputing a singular 'African sexuality'. What is suggested is a celebration of diversity, with sexual behaviour seen as 'experimental' (Parikh 2005: 154), 'playful and performative' (Nguyen 2005: 265), 'a discursive and sensual possibility....woven into the possibility of thinking about being modern' (Pigg and Adams 2005:21). The 'sexual self' seeking desire and pleasure through complex processes of negotiation is foregrounded. What tends to be missing from such accounts is the sense of fear and constraint faced by those who would be sexually active in contemporary Africa - more particularly women, but also men. The relational aspect of sex and the collective ways in which it is governed are also obscured, as are the collective struggles for protection and sexual change.

Finally there is a complete contrast between arguments which put 'permissiveness' and 'promiscuity' at the forefront of explanations of the dramatic diaspora of HIV across Africa and those which focus on coercion and asymmetrical relations - male violence against women, rape (increasing during wars), the extension of commoditisation of sex through forced or voluntary movements of labour and class differentiation, the lawlessness of shanty towns, domestic violence and so on. The incompatibility between the smiling picture of 'female freedom' (as per Caldwell et al) and Msimang's bleak account - "for many, the lived experience of being a woman in South Africa is defined by the fear of sexual violence..." (2000: 69) - is stark (see also Altman 2001: 7). This second perspective hardly figures in unidimensional accounts of 'African sexuality', though coercive sex is often rationalised in terms of 'traditional' male prerogatives. We cannot assume that any such accounts can be generalized to all areas and all kinds of people - in every case the complex local reality needs to be investigated. 


\section{Power and sexuality}

In the area in Tanzania where my study was conducted, messages of mutuality in sexual relations were generally received with scepticism born of a knowledge of power relations. The material cited here is from in-depth work in Lushoto District, both in the district capital and in a cluster of hamlets in the mountains nearby. The rural Sambaa people quoted here were mostly impoverished subsistence and peasant farmers, predominantly Muslim. This was an area from which extensive labour migration to urban areas had taken place in the past but this has now declined, with petty trading largely taking its place. It was an area with relatively low rates of HIV infection (less than $5 \%$ in 1996) ${ }^{v}$ but a survey $(n=100)$ conducted in the rural hinterland of the district capital revealed $45 \%$ of the respondents believing they knew of someone who had the disease.

In workshops with village women, pleas for greater mutuality were sometimes received in bewildered silence. More often women displayed a fierce distrust of men and a sense of hopelessness in the face of male power: "You get it from men!" one declared. "Let's say, my husband is in Dar es Salaam or Tanga - he is away and he comes home - that's how you get it!" "You can't do anything - he is your husband and if you refuse [sex] he will be angry...", said another. "Husbands won't agree! [to use condoms]". "They refuse!", chorused another group. Worse still, "We won't know [if he is infected]".

In male workshops, men concede that wives are fearful and suspicious, but they too are now afraid of being infected by adulterous wives as well as by other partners. Using condoms to protect their wives is not seen as acceptable, and men did not respond favourably to this idea. As I discovered by talking to men individually, it would be an admission of their own adultery or that of their wives and thereby their incapacity to control them. One man stated male expectations: "If the government in your home is bad then you will get [AIDS] - you need to rule your wives so that they don't go straying". But their sexual activity encompassed more than marital sex, with multiple sexual relations seen as quite normal, especially for younger men, and they were floundering as to how to protect themselves in this horrifying new world, where their control of women and women's sexual and reproductive capacity is poisoned by the prospect of lethal infection.

What comes across here illustrates Foucault's point precisely: "Sexuality [is]... an especially dense transfer point for relations of power" (1990 edition: 103). For Foucault, such relations operate "not by law, but by normalisation, not by punishment but by control, methods that are employed at all levels and in forms that go beyond the state and its apparatus" (89). The micro-politics of sexuality entail normative proscriptions and prescriptions about what can be done, with whom and when; what can be spoken of and what must remain unspeakable. 
However, what is elided in Foucault's work is that this regulation of social behaviour is strongly underpinned by cross-cutting forms of macro-level social power - the scaffolding of gender and age inequity is the most enduring, as well as political and religious/ritual power and class power (broadly here the power of resource control). And whereas such relations may be normalised, they are also underwritten by coercion. At the micro-level, sexual relations generally express the social power of older men over younger women, but it may be much more complex than this, with, for example, older women policing the social behaviour of younger women. In the rural setting of Tanzania I heard older women upbraiding young women in public to control their sexuality and they were also the guardians of chastity and sexual knowledge - albeit with a far lesser authority than they used to have (Bujra 2000). Such borrowed power was at the basis of institutions of initiation into adulthood throughout Africa (see

Tumbo-Masabo and Liljestrom 1994). The contradiction is that this policing of sexuality by older women is generally in the service of men rather than to fulfil female desires or to facilitate their assertion of their own rights as desirous sexual beings.

One reason why sexuality is so heavily regulated is because of its reproductive significance and the functionality of clear attachments of new life to old solidarities, but it goes beyond this logic. Relations between men are also fought out in terms of access to women within socially permitted categories. Where polygamy is licit then gerontocratic power is normally in play, with young men excluded and bidding for inclusion. Of the pastoralist and gerontocratic Maasai, Llewellyn-Davies noted the principle upon which legitimate sexuality is based: "it takes place between structural unequals" (1978: 207). Even where the object of sexual relations is far from marriage or reproduction, hierarchy is still in the picture. In South African townships 'love' is a dangerous game involving competition amongst young men for sexual partners. Wood and Jewkes (2005: 96) note that the "importance of men asserting hierarchies in their sexual relationships" entailed violence against women (when "young men enforced discipline and control over their female partners") and against other young men (as prestige in the peer group depends on success in fighting over girls). And even sexual relations between men (so often denied in Africa) are more often relations of inequality than mutuality. Examples are the young boys who used to be taken as partners by older and long-serving miners in South Africa (Moodie and Ndatshe 1994); or in Mombasa (Shepherd 1987) where "such relationships are almost always between a senior, wealthier partner and a junior, poorer one" (Standing and Kisekka's words, 1989: 106); or the situation described for northern Nigerian Hausa in the early 90s (Gaudio 2005) where the subversive relations of homosexuality also reproduce hierarchical and gendered views of the world. In this case, both gay and straight men saw women as subordinate and sexuality as associated with relations of dominance and inequality. Among homosexual actors (the specificity being in the act rather than in a discrete identity) one partner is often older or socially superior and men who play the female part are regarded as inferior. Indeed it is these hierarchical relations that 
give the action its sexual charge: "Sex between equals is cast as something feminine" (51).

I am not suggesting that any of this is exotically 'African' - indeed versions of these same power plays appear on sexual stages across the world (compare for example, Holland et al on the UK, 1998). In every setting the micro-politics of sexuality reflect a strategic conjuncture of power struggles at more macro levels. Turning this around, it is also the case that demonstrating effective control in matters of sexuality is a significant marker of power. The proscriptions and prescriptions are held in place by deference to those who can punish - parents, husbands, 'elders', religious leaders. When AIDS emerges as a terrible threat to existing patterns of sexual behaviour and expression of sexuality, it is also a threat to the power relations which upheld them.

Whereas the powerful inveigh against AIDS as 'God's big stick' (as the Muslim sheikh in the Lushoto village I studied was wont to do), and along with other elders point the finger at youth (especially young women) for promiscuous behaviour, it is less easy to identify sexual expression that can be prescribed as safe: even 'faithful wives' are not immune. And it is difficult to repress the 'shameful' talking about sex that has suddenly erupted. In this dilemma many call for a return to old prohibitions and familiar punishments. In Lushoto one elderly man (a traditional doctor or mganga) spoke feelingly: "These days people break customary rules and talk openly about sex ... even in front of mothers!...People used to be driven into the forest if they committed adultery - my grandmother was driven out by the elders". And if some men feel the need to renew "the government in your home", even women may concede that men still have the right to violently chastise women - twenty out of fifty women surveyed agreed that a husband could beat his wife (with reason). "You are hit and learn your lesson" said one married woman. And asking for condom use may be asking to be beaten.

\section{Material dependence, independence and sexuality}

Men's power has a material base as well as a coercive edge. Dependent women cannot escape it. In this rural area women's livelihoods rest almost wholly on access to the land of their husbands or fathers. Women marry into the village and their position on the death of their spouse is only assured if they have grown sons. Even in this case, wife inheritance by the husband's brother was the norm in the past, though today some widows refuse to be inherited, and others hang on to property or businesses acquired by their deceased spouses. Divorced women or those without children must usually return to their natal homes. In one case, a young woman, still childless, simply disappeared from the village after her husband was buried on dying of AIDS. One of the most distressing cases I encountered (albeit extreme) was that of a woman of 35 living in a small, dark and isolated old mud house with holes for windows. She was in a very depressed, almost catatonic state, clearly unwell. Her husband had died the previous year of 
"TB" - commonly an opportunistic symptom of AIDS. As she said "people die but you don't know if it was AIDS". She may also have been infected, or believed she was. At one point she said that she didn't know about AIDS (its symptoms, how it is caught etc.) and therefore wasn't sure if she could be in danger herself. She had been inherited by her husband's brother, a man who sold fish in the district capital, but she did not live with him and appearances suggested that he took little care of her. She had five young children and scraped a living on a small plot belonging to her dead husband. When we asked her what she would teach her children she said: "If I am still alive, I will teach them". What? "I don't know". Certainly she claimed to know nothing of condoms. Mutuality is not going to flower in such a setting. Women with nothing have few choices.

Amongst the choices that women might make are to pursue more independent lives beyond the rural setting. Often this is an outcome of adversity, following divorce or widowhood; but young women may also leave hoping to better themselves through urban employment. One or two local girls from the village commuted to work in bars in the district capital of Lushoto; others found work as domestic servants further afield. Some of the currency that is given to ideas of 'African promiscuity' has borrowed from the label of 'femmes libres' given to women in cities and towns areas where, it is assumed, they pursue more liberated lives, and where sexuality is less constrained by cultural prohibitions. One woman in my study, interviewed on an extensive visit to her home village following marriage to a local man working in an urban area, pin-pointed the difference: "Here there is little promiscuity (uhuni) because you are watched, but in towns there is more freedom". However, it would be misleading to regard the lives of women in African urban settings, whether single or married, as allowing for the free pursuit of sexual pleasure. To begin with, such settings are highly diverse, sometimes with enclaves where cultural restrictions are still enforced. Socio-economic differentiation is also marked in urban areas, making sexual relations an expression both of class position or class disparity, shot through with gender inequities at all levels (Bujra 2006). There is often a more overt transformation of desire into instrumentality as women bid to survive or to improve their social positions. Commoditised sex or schoolgirl sex with sugar daddies is rarely the satisfaction of desire (Silberschmidt and Rasch 2001). And when women (whether struggling to get by or establish a career or hold down a steady job) choose lovers over 'inside marriage' or the restrictions imposed by marriage, it would seem they do this more in pursuit of economic ends than of untrammelled desire (see e.g. Karanja in Parkin and Nyamwaya 1987 on Lagos; or Nelson, 1987 on Nairobi; Haram on Tanzania 2005; also Wood and Jewkes 2005). Sexual instrumentality is not limited to survival strategies in situations where women lack labour market opportunities. It is also encountered as a bid for social mobility.

The vulnerability of younger women to coercive sex in all settings is notable though it appears clear that there is a mixture of instrumentality and yearning for adult status that leads many into danger. Even high socio-economic status does 
not protect here - indeed it may exacerbate the problem. I have noted elsewhere the statistic that in Tanzania, "youth from the highest wealth quintile conceded to more risky sex than any other category, whilst the young women amongst them were more likely to have had sexual relations with men ten or more years older than themselves (sugar daddies?) and more of them also reported that they had been coerced into sex... there is a chilling intersection of socio-economic position with gender relations here, suggestive not just of greater disposable income and power amongst better-off men, but of young women who are struggling to find acceptable outlets for their sexuality in situations of relative freedom" (2006; citing THIS stats). The freedom described here is temporary - an extended adolescence, a secret life beyond the eyes of parents, of not yet having to earn a livelihood but of desire for material possessions.

It is worth considering what happens to instrumental sex when sex - particularly with many partners - becomes an invitation to death. In a small study of 'independent' women $(n=18)$ in the bustling district capital, Lushoto ${ }^{\mathrm{vi}}$, I found few who were openly selling sexual services, but many who had strategically added sexual liaisons to other modes of income earning (petty trade, renting out rooms, owning or working in bars or guest houses, selling cooked foods or alcohol). Their view of men was on the whole cynical. Men, even husbands, could not be relied on. "Men harass you, they want to be fed. If you have nothing they're not interested and seek other women". "[Husbands] take money and lose it, 'playing', or 'business', or other women, or drink". But these women are less fatalistic than those in the villages. They are resourceful in making money and keeping it from their partners, knowing that men can disappear. They also make connections between those who "have many boyfriends" and die of AIDS and consequently are more likely to be protecting themselves.

Silberschmidt has argued provocatively that "socio-economic change in rural and urban Africa has increasingly disempowered men", leading to their "lack of social value and self-esteem" (2004::234). Men whose livelihood opportunities have declined, given the collapse of migrant wage labour and the encroachment of capitalist property relations in land, are increasingly "unable to fulfil social and other expectations". In consequence '[m]ale control over women weakened' (236). She concludes: "Deteriorating material conditions have seriously undermined the normative order of patriarchy" (240). Conversely women have empowered themselves and learnt to rival men economically, thereby threatening men's fragile egos and spurring them to reassert their masculinity in aggressively sexual ways ${ }^{\text {vii. }}$.

This is a scenario that is familiar in many other parts of Africa. The problem with the thesis is only that it essentialises men. Some men have done all too well out of Africa's current economic crisis - and as class differentiation has increased so has the predatory sexual pursuit of young women. Money buys sex. Conversely many women - wives, daughters - have themselves been brought down in the wake of men's general impoverishment and are not always in a position to gain 
an alternative economic base. My argument would be that it is not only men's economic circumstances which drive their sexual behaviour; it is also currently their vulnerability to deadly infection from women which spurs a re-consideration of masculinity (Bujra 2002). Silberschmidt is right to underline the relational aspect of masculinity - that it is defined within gendered relationships, where both women and other men are audience and co-producers. Only together do they have the capacity to transform sexuality, and changed circumstances spur rethinking.

\section{AIDS and the new power struggles}

AIDS has thrown old certainties into question. The authority of husbands, fathers and local elders is now in question, as I observed in Lushoto. People begin to talk more openly, because even men realise that they must "learn how to be safe" and "we have to talk about it now". Unspeakable things are said. "Better to be beaten than to die!" proclaimed one woman, in a discussion about how husbands might be encouraged to use condoms. As the custodians of custom and practice (mila na desturi), men began to question practices like widow inheritance or speaking to sons and even daughters about sexual behaviour ("we have to do it if we want our children to live", see Bujra 2002). Doing this is deeply shameful (sex talk between adjacent generations having always been unthinkable); the pain derives from challenge to an acceptable order of power

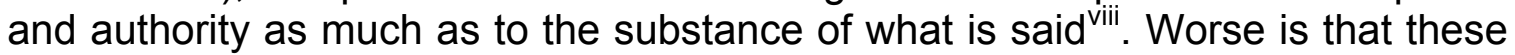
days children "don't listen" and "you'd be asking to be insulted!". Youth cannot any longer be held to an insistence that "they obey their elders". When village people find speaking out is to break codes of respect or invite disobedience, whilst a respectful silence is to court the grave, it is no wonder that they feel, "The world is finished".

If 'established authority' all over Africa has been put into question by the spectre of AIDS, conversely there has arisen a new cadre of 'experts' on sexual behaviour: a professionalized category of workers from state, local or international NGOs. They prescribe new rules of engagement for sexual activity zero grazing (single partners), abstinence, fidelity, use of condoms and so on. The power and authority of these new experts is materially enhanced, through donor funding and the creation of alternative and competing power structures promoting forms of sexual behaviour and new demands which transgress and threaten local power. For example in the Lushoto village, external donors were ready to support a young women's AIDS awareness group and to favour and promote a local woman who did not have the confidence of village elders and leaders, thereby undermining them and leading to particular resentment from young men (Bujra 2000).

There is also a shift away from local (often represented as ethnicised) sources of authority towards more national and macro-levels - though this was of course pre-figured in the extension of state power in general from colonial times - in 
taxation, schooling and health, whilst in the era of neo-liberalism the state's capacity to deliver has been radically diminished. Nevertheless it can transmit potent messages. As President Museveni of Uganda emphasised early on, the new messages about safer sexual behaviour were to be proclaimed in "public places, in private meetings and in our homes and at all functions - from wedding ceremonies to funeral rites..." (speech on World AIDS Day, 1988, cited in Standing and Kisekka 1989: 126). More recently the entire leadership of the Tanzanian government, including the President and his wife, have been publicly tested for HIV in order to emphasise that the epidemic is a national concern (BBC World Service news, 14 July 2007). Every African country now has a national AIDS campaigning organization.

There are parallels to the intrusion of the state into the affairs of home and bedroom. This is a pattern that proceeded inexorably with the rise of capitalism in Europe, which first divided the domestic from the public and then intervened in both so that "sexuality is subject to control and manipulation by economic imperatives and state interests" (Battacharyya 2002:57). "Histories of state intervention into sexual practice... [entail] injunctions to obedience for some wider social good, often calling for abstinence from certain practices or some other limiting of sexual expression" (op cit: 64 ). Colonial state power was similarly deployed in defining legitimate forms of marriage or containing extra marital sex work (Cornwall 2005: 5-6). Battacharyya concedes that state attempts to control the private and the intimate have not prevented its occasional extensions of liberatory rights to women or those labelled as deviants; whilst there are contradictory struggles between state interests in imposing social order and sections of capital concerned to profit (where "sexual experimentation and diversity can itself offer another great opportunity for sales": 62).

Nowhere can we equate the interests of state completely with those of capital, and less so in underdeveloped Africa than elsewhere, but it is clear that here too there is a contestation between the pursuit of public health and constant pressures for its privatisation (through private doctors and pharmaceutical companies) which AIDS grimly exposes. And it cannot be denied that the new vocabulary of sexual prescription is another form of 'privatisation' by way of state and NGO intrusion into the heart of the family.

\section{All that is sweetest in life}

Across Africa, given the threat of HIV, both men and women are now referring to what is being lost. A village woman in Lushoto spoke feelingly of how AIDS threatens: "all that is sweetest in life". This is both sexual satisfaction and also the shadow that is cast over getting pregnant. "Better that I live alone like a young child [i.e. sexless], not marrying, not having children, for fear of this illness". Sexual yearning is normal, but now it is hazardous: "At the time of desire [tamaa] you go with a man and you don't know he has this illness". The prospect of having to forego sexual relations is painful, even if the partner is discovered to be 
infected. Women want to believe they could "stop having sex - but you couldn't!". The future is diminished when people contemplate a life where "each one must live alone", or sons must be warned: "not to be so desirous of women". In this rural setting women have rarely thought of themselves as free sexual beings wives cannot refuse sex or indeed demand it. Desiring sex, they also feared men's 'excessive' sexuality: "men are never satisfied, they're like chickens", "it's their way and they cannot give it up". "These days", said one woman who had a child born out of wedlock, "you are afraid of men and of sex - you didn't used to be". They are speaking of men's seeking sex both within and outside marriage (although they concede that women may do this too).

Men were also concerned about the curbs on sexuality which AIDS had brought. The threat was both from wives and from "going with women you don't know". Sex had suddenly become very dangerous. Men now needed to exercise "selfcontrol - difficult but possible" claimed one, whilst others were struggling with the complexities, not of mutuality but of self-protection. "If you have six or seven 'friends", said one, "then you should reduce the number. But if I reduce to one and use condoms with her, how will it help? Condoms can split". Addressing the facilitators of a workshop he added despairingly, "Why don't you advise us to give up sex altogether?" One of the few men who spoke openly in public of his experience of using condoms in extra-marital sex is a telling example of current struggles. Aged around thirty, his sister had died of AIDS (again his public admission of this was very unusual). He had been a successful trader but his sister's illness had taken all his savings and "I have fallen far. I am just at home now, working for others as an agricultural labourer". His sister had also been a small-scale trader in nearby towns and "she met someone who gave it to her". Now married, he expresses the anxiety that men have over controlling women's sexual desires: "married people are unsafe too. A wife might be given money to go to the market and there she is offered money or gifts by a man to do sex - the husband hasn't any idea, he sleeps with her as usual... Married people need to discuss and be concerned and protect themselves. Some use condoms for protection, or to space births, or because they are afraid of each other. Not that a wife can demand this - unless you have been away and she is shocked at your appearance when you return, or you start to get very thin. Using condoms is better than abstaining from sex".

What is striking in this passage is not only the level of mistrust between sexual partners that is now normal, but the way that the messages of the new experts are being weighed up and to some extent put into practice. Both men and women are aware that "if you abstain you don't get it", but abstinence was repellent. Most men did not think they could control their longings, whereas women could not insist on such a course of action - and both parties wanted children. Condoms were similarly problematic. Seen as a pleasure-killer and alien to intimacy, even the facilitators in our workshops conceded that wearing condoms was "like eating maize porridge with gloves on", as something which had to be endured if life was to proceed. More commonly men devise strategies about where the greater risk 
is - they might use condoms "in the alleyways" but perhaps not "with those who haven't been anywhere". Or, "Outside you use; inside you don't use them". And of course condoms also prevent pregnancy so they did not address the desperate need of those who want children to be able to trust each other. It is here that messages of mutuality are weighed against men's understandable impulse to retain power over women in sexual matters. The man just quoted says: "Married people need to discuss and be concerned and protect themselves", but men are wont to 'tell' or 'warn' wives to behave properly, rather than opening up discussion about their own behaviour. Occasionally there are breakthroughs: "we warn each other" or "I care for my wife so that she doesn't desire others", and the recognition that a man "should not infect his wife".

What we hear in these exchanges are rehearsals for new forms of dialogue and practice even if the performance itself is rarely staged ${ }^{\text {ix }}$. Although some forms of collective action and mutual dialogue were initiated here (described elsewhere, Bujra 2000, 2002), they were undermined by gendered and generational tensions. A young women's group foundered in the face of older women excluding them from exploiting donor opportunities, and a village group of men and women operated only fitfully as men assumed control, older women remained respectfully silent and younger women could not easily assert themselves. In the last analysis women face men in lonely intimacy where they find it almost impossible to put words into action.

In the district capital, independent women are more able to insist on their own safety. They aim to demand condom use and some succeed, as one woman told me. She supplemented her income of maize selling with male 'friends', entertained at home, and expected them to use a condom: "If a man refuses you say No. They don't insist if it is 'love' in your room - not like outside". The men bring the condoms but women can also get them free from the local hospital. And where men threaten beatings, "you may hit back! Fight each other". Others, even young women, have concluded that abstinence is the only solution. As a woman shopkeeper said of sexual liaisons, "you could be seeking money in ways that are dangerous and end up with AIDS. I don't have sex, it's safer". Abstinence, living without a man, may not just be a life without sex - it may be a life without a livelihood, unless alternatives can be found. Many of these women had found other means to economic survival and could make a choice.

It was a married woman in town who argued exceptionally for mutuality between sexual partners as the best antidote to infection: "You must talk to each other and maybe use condoms. Peace and trust in the house so that husbands don't go out looking for other women but are satisfied at home. Both should satisfy each other. Some women have several children but have never gained full sexual satisfaction". The insistence that women might have a claim to sexual satisfaction is notable as well as unusual here ${ }^{x}$. Given the usual patterns of power relations between men and women, it is men who in most cases have the power to pursue sexual pleasure, whereas for women this seems to be incidental, a matter of 
good fortune, not of right. 'Empowered female sexuality' is nearly always transgressive (Holland et al 1996: 256). This is highlighted in recent discussions amongst African feminists.

\section{AIDS and feminism in Africa}

A 1982 issue of Feminist Review (UK) argued that "to politicise sexuality has been one of the most important achievements of the Women's Liberation Movement". Ifi Amadiume commented at the time that: "These priorities of the West are of course totally removed from, and alien to the concerns of the mass of African women" (1987:9). The 'concerns' of African women were understandably defined in terms of impoverishment and lack of development. By contrast, and an era away in terms of the intervening AIDS epidemic, Pat McFadden has recently mounted a strong plea for the liberation of African women to freely pursue sexual desire as a project of the self. In an on-line article in Feminist Africa entitled, "Sexual pleasure as Feminist choice" (2003), she effectively weaves together the issue of sexuality/pleasure with the question of HIVIAIDS and a renewed patriarchy in Africa. Arguing that the discourse of rights and of choices has so far been limited "within the parameters of cultural prescriptions about women's roles and bodies", she insists that: "Choice ...needs to be envisaged as something more than simply options for safeguarding ourselves against sexually transmitted diseases... as going beyond demands for safety and protection from sexual violation in the public and private sphere. It has to be everything that we have not yet begun to say and do as women who know that our lives can be different, if we only have the courage to step out of the cages of cultural practices and values that not only oppress us, but also presume to dictate the terms of our 'freedom'”.

McFadden goes on to argue that to seize this freedom, women need to embrace "the erotic as power" (quoting Lorde, 1982) and to appropriate "liberating discourses on sexuality, pleasure and desire" $(4,3)$. Whilst seeing such bids as political - and thereby presumably to be struggled for collectively - there is here an underlying theme of 'individual autonomy' and love of self. Foucault leads us down the same path in his later volumes of the History of Sexuality. There is also a tendency (common in radical feminism) to play down the features that differentiate - and divide - women and which give the promise of choice a very hollow ring - especially to the majority of women in Africa. It is not that women do not long for sexual fulfilment and feel cheated by how HIVIAIDS has robbed them of any easy enjoyment. But if women had limited choices before, given patriarchal social regimes, their choices now may entice death if they cannot protect themselves. The mountainous difficulties in the way of women's need for self-protection and their struggles for mutuality in sexual relations with men need more recognition and critical analysis, not more exhortations to choose. The point is made again by Pereira (also in Feminist Africa, 2003:2). She adds that: "There is something ironic about a feminist argument that asserts the primacy of sexual pleasure and choice for women, independent of considerations for 
reciprocity between sexual partners, whether male or female..." And women's own sexual freedom also carries the responsibility not to knowingly pass on the virus. We have an instance here of what Pigg and Adams describe as 'contemporary sexual identity politics that advocate the possibility of specific pleasures and erotics without moral blame' (2005:2, my emphasis).

Elsewhere, feminists have seen in AIDS an opportunity for rethinking the issue of sexuality for women, an opportunity to "redefine sexuality and negotiate new meanings" (Richardson 2000:126). Richardson points out that 'safe sex' was never on the agenda anywhere for women and not therefore something which has to be regained (in Foucault's terms, the demand that "tomorrow sex will be good again": 1978: 7). Richardson comments that: "This is a gendered [male, including gay male] account of the significance of HIVIAIDS for contemporary understandings of sexuality" (124). Feminists on the other hand, "had a great deal to say about 'safer sex', long before HIV appeared on the scene" (125). In the West it had mobilised women in struggles for contraception and against rape and other forms of sexual violence, as well as exploring alternatives to the almost exclusive focus on vaginal intercourse in heterosexuality. Some of this is echoed in struggles amongst African feminists, influencing the course of AIDS interventions. Notable is their influence in shifting the exclusive blame for HIV transmission from women (so common in the early days, see Bassett and Mhloyi 1991), to looking at its impact and imperatives for men as well. This is embodied in the goals of the continent-wide initiated Society for Women and AIDS in Africa.

Sexual pleasure for women requires a degree of mutuality which is also the agenda for addressing AIDS. Mutuality has the potential to equalise. But it is not the sexual pleasuring of self that is the goal here: sexual pleasure is not a right but rather a recognition of mutual responsibilities; both men and women taking responsibility for each other's pleasure, as well as seeking the satisfaction of their own.

\section{Conclusion}

In this paper I have traced the way in which AIDS in Africa has put power relations at all levels in question simply because it interrupts the assumption of control over female sexuality on which men have always built their dominance. As the directive power of husbands, fathers, men in general, local leaders and the state has been put in question; novel prospects of power to transform with others (Rowlands 1997) has been given an (albeit ambiguous) drive by the "new experts' of the NGO/INGO community, but also by women themselves, daring to challenge the status quo. Resistance itself can transform power relations - from bids for domination over others to collective action in the achievement of particular goals. The women I studied in Lushoto were beginning to explore this possibility through dialogue and small-scale organization; in other areas the process has gone much further. In particular those who are stigmatized and blamed for transmitting infection have begun to organize in their own right all 
over Africa - sex workers to use condoms, women and youth to campaign for programmes of prevention and care, people living with HIVIAIDS (PLHA) to promote the possibility of positive survival with AIDS, gay people to resist discrimination ${ }^{\mathrm{xi}}$. All such movements are subversive in that they extend 'talking about sex' to making claims for the right to safe sex, a sexuality which is responsible as well as life-protecting. We need to concede, however, that rights agendas can also be contradictory, with proponents who join the blame game respectable women inveighing against prostitutes and gays, the demonisation of youthful sexuality etc.

I have also tried to show that, despite the way in which sexuality is bound up with the micro and macro-politics of gender, AIDS has forced men and women in Africa (and elsewhere) to imagine a wholly different way of conducting sexual relations. I have listened to ordinary people talking about sex in new ways that would demand more mutuality and argued that the prospect of death and disease gives this talk more charge than it could have had before. Not only does this hold out the potential for addressing HIV transmission, it also raises awareness of female desire and sexual agency and questions the very inequities of gender relations. As a married woman in rural Lushoto replied, when asked if she feared AIDS, "Not me - I have never slept with anyone except my husband.... But maybe him - after all, we are two!"

\section{Notes}

${ }^{i}$ Research was carried out in Tanzania over the period 1994-2000 as part of the Gender and AIDS project funded by the ESRC (UK) and jointly coordinated by Janet Bujra and Carolyn Baylies, working with a team of African scholars and activists. The material cited here is from my own in-depth work in Lushoto District. Research included extensive participant observation, a base-line survey based on a stratified sample (50/50 men and women; range of ages and socioeconomic position); as well as action research with local groups (women/young people/village leaders). All work was carried out in Swahili.

ii The other key message is, of course, abstinence, which may or may not require mutuality, and is irrelevant to marital relations, but allows for the social control of young people and is much favoured by religious organisations and by some international donors (particularly the US).

iii Writing on Mafia in Tanzania, Caplan also reports setting where sexual pleasure is deemed important for both parties and is - or was - taught in initiation rituals (1976).

iv Dry sex is practised in parts of West Africa (on Ghana see Bleek, 1976) and in Central Africa (on Zimbabwe see Sayagues 2000). Involving the insertion of herbs to dry up vaginal secretions for men's greater pleasure, it also causes abrasions that lead more easily to HIV infection.

${ }^{v}$ This is very much a local estimate from health sources, based on testing blood donors. The estimated national prevalence rate was at the same time just over $8 \%$ (UNAIDS/WHO 2000). . Extreme caution should always be exercised in using such figures, given their mode of production (see Whiteside et al, 2006:27).

vi This was a more cosmopolitan setting than its rural hinterland, with around $45 \%$ of the sample Sambaa but others from a variety of ethnic groups, including a few women from very distant areas.

vii That this is not always the outcome and can lead to women demanding more reciprocal relations with men is suggested by a colonial example from Ghana. Allman describes how in 
Asante unmarried and divorced women began to compete with men in setting up cocoa farms and trading. Chiefs tried to reassert men's control by imprisoning such women and insisting they name a man who would marry them. The rising economic independence of women led them to resist the constraints of marriage, they demanded more equality in marriage: "the mutuality of conjugal obligations" (2005: 203). In the end they found ways to subvert attempts to control them by paying male accomplices to pay their release fees or even paying themselves.

\footnotetext{
viii In contrast, the initiation of young people generally involved the graphic instruction of young women (and men) in sexual matters, but they were taught by people of alternate generations, equivalent to grandmothers/fathers, often in secret. However, the elaborated initiation training and rituals of the past have all but disappeared in many parts of Africa (see Ahlberg et al 1999; Tumbo-Masabo and Liljestrom 1994). Private talk about sexual matters with one's age peers is also acceptable. 'Silence' about sex has always been situationally defined.

${ }^{i x}$ It might be suggested that a lack of appropriate sexual vocabulary is an inhibition to more informed discussion of sex. While partially true, vocabularies soon expand to fill social demand, and in our work we found that euphemisms such as 'it' and 'thing' were deployed and well understood in context. Initially we were uncertain how to translate terms like 'sexual relations'. Our Tanzanian linguist offered 'kujamiana' (to have relations with each other), but this met with blank incomprehension. People's own usage was 'kufanya mapenzi' (to make love) , 'kukutana mwili' (the meeting of bodies), or in one case 'kusongelea' (to grind, press against). For a thoughtful exploration of the debate in the South African context see Crawhall 1999.

${ }^{x}$ This woman was the wife of a Christian pastor. They were not well-off and she worked full time as a labourer on local road projects and occasionally as a volunteer mid-wife.

xi A recent example of organising amongst Lesbian, Gay, Bisexual, Transgender and Intersex (LGBTI) people in East Africa is sponsored by the Urgent Action Fund - Africa (funded by the Ford Foundation and HIVOS amongst others). Finding themselves in confrontation with states upholding 'public morality', many must live secret lives and open movement building is rendered dangerous. Instead they have set up a process of "internet mobilisation and organising" (Kiragu and Nyong'o 2005: 11) to allow them to speak out.
}

\section{Acknowledgements}

An earlier version of this paper was presented at the International Sociological Association, $16^{\text {th }}$ World Congress of Sociology, Durban, South Africa, July 2006. My unbounded thanks to those who have commented critically and generously on succeeding versions: Pat Caplan, Jelke Boesten, Graeme Chesters, Martin Pearson and Maggie Bolton.

\section{Bibliography}

Adams V and Pigg SL: Sex in Development: Science, Sexuality and Morality in Global Perspective, Durham/London: Duke University Press, 2005

Ahlberg B: "Is there a distinct African sexuality? A critical response to Caldwell", Africa, 64, 2, 1994 
Ahlberg B, Kimani V, Kirumbi L, Kaara M and Krantz I: "Male circumcision: practice and implication for transmission and prevention of STD/HIV in Central Kenya" in C Becker, J-P Dozon, C Obbo and M Toure, Experiencing and Understanding AIDS in Africa, Dakar/Paris: Karthala/CODESRIA, 1999

Allman J: "Rounding up spinsters: gender chaos and unmarried women in colonial Asante" (1996), in Cornwall A (ed), Readings in Gender in Africa, London: James Currey, 2005

Altman D: Global Sex, University of Chicago Press, 2001

Amadiume I: Male daughters. Female Husbands, London: Zed Books, 1987

Arnfred S: "Intorduction: Rethinking Sexualities in Africa" in Rethinking Sexualities in Africa, Almqvist and Wiksell Tryckeri AB, Sweden, 2004

Bassett $\mathrm{M}$ and Mhloyi M: "Women and AIDS in Zimbabwe: the making of an epidemic", International Journal of Health Studies (pp143-156), 21, 1, 1991

BBC News: Tanzanian leader takes AIDS test", http://news.bbc.co.uk/go/pr/fr/-/hi/world/africa/6899134.stm

Bhattacharyya G: Sexuality and Society: an Introduction, London: Routledge 2002

Bland L: "The shock of the Freewoman journal: feminists speaking on heterosexuality in early $20^{\text {th }}$ century England" in Weeks $\mathrm{J}$ and $\mathrm{J}$ Holland: Sexual Cultures: Communities, Values and Intimacy, Basingstoke: Macmillan Press, 1996

Bleek W: Birth control and sexual relationships in Ghana, a case study of a rural town", Amsterdam: Antropologisch-Sociologisch Centrum, 1976

Bujra J: "Target practice: Gender and generational struggles in AIDS prevention work in Lushoto", in Baylies C and Bujra J with the Gender and AIDS Gp: AIDS, Sexuality and Gender in Africa: Collective Strategies and Struggles in Tanzania and Zambia, London: Routledge, 2000

Bujra J, "Targeting men for a change: AIDS discourse and activism in Africa", in F Cleaver (ed), Masculinities Matter! Men, Gender and Development, London: Zed Books, 2002

Bujra J: "Class relations: AIDS and socio-economic privilege in Africa", Review of African Political Economy 107, 2006

Caldwell J, Caldwell $P$ and Quiggin P: "The social context of AIDS in SubSaharan Africa", Population and Development Review, 15, 2, 1989 
Caplan P: "Boys' circumcision and girls' puberty rites on Mafia Island", Africa, 46, 1976

Cornwall A: "Introduction: Perspectives on gender in Africa" in Cornwall A (ed), Readings in Gender in Africa, London: James Currey, 2005

Crawhall N: "Using a sociolinguistic approach to safe sex promotion in Cape Town: the challenges of multiculturalism", in C Becker, J-P Dozon, C Obbo and $M$ Toure, Experiencing and Understanding AIDS in Africa, Dakar/Paris: Karthala/CODESRIA, 1999

Dualeh, Riqiya Haji: "Women and Reproduction in Somalia" in Women and Reproduction, Report SAREC/SIDA seminar, Visby, 1983

Feminist Review: Editorial, 1982

Foucault M: The History of Sexuality, Vol. 1 1978, translated, Penguin ed. 1990 Foucault M: The Use of Pleasure, Vol. 2 of The History of Sexuality, 1984, Penguin ed. 1992

Foucault M: The Care of the Self, Vol. 3 of The History of Sexuality, 1984, Penguin ed. 1990

Gaudio R: "Male lesbians and other queer notions in Hausa", (1998) in Cornwall A: Readings in Gender in Africa, Oxford: James Currey, 2005

Haram L: "'Eyes have no curtains': The moral economy of secrecy in managing love affairs among adolescents in Northern Tanzania in the time of AIDS", Africa Today, 51, 4, 2005

Heald S: "The power of sex: some reflections on the Caldwells' 'African sexuality' thesis", Africa, 65, 4, 1995

Holland J, Ramazanoglu C, Sharpe S and Thomson T: The Male in the Head: Young People, Heterosexuality and Power, London: The Tufnell Press, 1998

Hooper E: The River: A Journey back to the Source of HIV and AIDS, London: Penguin, 2000

Iliffe J: The African AIDS Epidemic: A History,, James Currey 2006

Karanja, Wambui wa: “'Outside wives' and 'inside wives' in Lagos, Nigeria”, in Parkin D and Nyamwaya D (eds), Transformations of African Marriage, Manchester University Press/IAI, 1987 
Kiragu J and Nyong'o Z, LGBTI Organising in East Africa: The True Test for Human Rights Defenders, Urgent Action Fund-Africa, 2005 [UAF-LGBTI Report Final 1.pdf], 2005

Kisekka M: "Focussed group interviews - Uganda" in Standing $\mathrm{H}$ and Kisekka M: Sexual Behaviour in Sub-Saharan Africa: A Review and Annotated Bibliography, ODA: London, 1989

Llewellyn-Davies M: "Two contexts of solidarity amongst pastoral Maasai women" in Caplan P and Bujra J: Women United, Women Divided, London: Tavistock,1978

Malinowski B: Sex, Culture and Myth, London: Rupert Hart-Davis, 1963 ed

McFadden P: "Sexual pleasure as feminist choice", Feminist Africa, 2, 2003 [www.feministafrica.org/fa\%202/02-2003/sp-pat.html]

Moodie T and Ndatshe V: Going for Gold: Men, Mines and Migration, Berkeley and Los Angeles: university of California Press, 1994

Msimang S: "African Renaissance: where are the women?", Agenda 44, Durban, 2000

Nelson N: 'Selling her kiosk': Kikuyu notions of sexuality and sex for sale in Mathare Valley, Kenya", in P Caplan, The Cultural Construction of Sexuality, Tavistock , 1987

Nguyen N: "Uses and pleasures: Sexual modernity, HIVIAIDS, and confessional technologies in a West African metropolis", in Adams and Pigg 2005, qv

Parikh S: "From auntie to disco: the bifurcation of risk and pleasure in sex education in Uganda", in Adams and Pigg, 2005, qv

Pereira C: "Where angels fear to tread' Some thoughts on Patricia McFadden's 'Sexual pleasure as feminist choice'”, Feminist Africa, 2, 2003 [www.feministafrica.org/fa\%202/02-2003/sp-charmaine.html]

Phillips O: "The invisible presence of homosexuality: Implications for HIVIAIDS and rights in Southern Africa", in E Kalipani, S Craddock, JR Oppong znd J Ghosh (eds), HIVIAIDS in Africa: Beyond Epidemiology, Oxfoerd, Blackwell, 2004

Pigg S and Adams V: "Introduction: the moral object of sex", in Adams and Pigg, qv 
Poewe K: Matrilineal Ideology: Male-Female Dynamics in Luapula, Zambia, London: Academic Press/IAI, 1981

Richardson D: Rethinking Sexuality, London: Sage, 2000

Rowlands J: Questioning Empowerment, Oxfam, 1997

Sayagues M: "Zimbabwe's last sexual taboo", Orbit, 77, 2000

Shepherd G: "Rank, gender and homosexuality: Mombasa as a key to understanding sexual options" in Caplan P, The Cultural Construction of Sexuality, Tavistock, 1987

Silberschmidt M: "Masculinities, sexuality and socio-economic change in rural and urban East Africa", in S Arnfred (ed), 2004 qv

Silberschmidt $\mathrm{M}$ and Rasch V: "Adolescent girls, illegal abortions and 'sugar daddies' in Dar es Salaam: Vulnerable victims and active social agents", pp. 1815-1826, Social Science and Medicine, 52, 2001

Standing $\mathrm{H}$ and Kisekka $\mathrm{M}$ : Sexual Behaviour in Sub-Saharan Africa: A Review and Annotated Bibliography, ODA: London, 1989

Stopes M: Married Love, AC Fifield, 1918 (Also reprint, Oxford University Press, 2004)

THIS: Tanzania HIVIAIDS Indicator Survey, Tanzania Commission for AIDS, National Bureau of Statistics and ORC Macro: Calverton, Maryland, 2005

Tumbo-Masabo Z and Liljestrom R (eds) Chelewa Chelewa: The Dilemma of Teenage Girls, The Scandinavian Institute of African Studies, 1994

UNAIDS: Report on the Global HIVIAIDS epidemic, June 2000, http://www.unaids.org

Whiteside A, T Barnett, G George and A van Niekerk: "Through a glass darkly: data and uncertainty in the AIDS debate", pp 15-39 in A van Nierkerk and L Kopelman (eds), AIDS and Ethics in Africa, California, Left Coast Press, 2006

Wood $\mathrm{K}$ and Jewkes R: "'Dangerous' love: reflections on violence amongst Xhosa township youth" (2001) in Cornwall A: Readings in Gender in Africa, Oxford: James Currey, 2005

Wright H: The Sex Factor in Marriage, Vanguard Press, 1931 



\section{International Centre for Participation Studies \\ Department of Peace Studies \\ University of Bradford \\ BD1 1DP}

Working Paper No. 8, 2007 